\title{
THE BALANCED SCORECARD AND EFQM WORKING TOGETHER IN A PERFORMANCE MANAGEMENT FRAMEWORK IN CONSTRUCTION INDUSTRY
}

\author{
Mladen VUKOMANOVIC, Mladen RADUJKOVIC \\ Faculty of Civil Engineering, University of Zagreb, Zagreb, Croatia
}

Received 20 Sep. 2011; accepted 21 Dec. 2011

\begin{abstract}
In the recent years the Balanced Scorecard (BSC) and EFQM Excellence Model (EFQM) became very popular performance management (PMM) models. However, many studies showed their flaws, especially in communicating, integrating and aligning Key Performance Indicators (KPI) with strategy, setting targets and conducting benchmarking. BSC or EFQM have always been used alone and regarded as exclusive PMM tools. In contrast, this study introduces a novel PMM framework that relies on the strengths of both BSC and EFQM. The framework uses the Analytic Hierarchy Process (AHP) to connect these two models. At first, AHP is used for setting priorities among competitive strategic objectives and afterwards for selecting KPIs against SMARTER (Specific, Measurable, Achievable, Relevant, Time-bound, Encouraging and Rewarding) criteria. By verifying the framework on the construction industry we discovered that companies can integrate EFQM and BSC to conduct benchmarking, identify best practice, align strategy with the competitive surroundings and selecting strategy aligned KPIs. Using this framework, construction companies can thus achieve strategic control that otherwise by just using BSC could not be achieved. These findings are important because they bring a new perspective on managing organizations and confront many authors who have put EFQM and BSC against each other.
\end{abstract}

Keywords: performance management; framework; EFQM Excellence Model; the Balanced Scorecard; business excellence.

Reference to this paper should be made as follows: Vukomanovic, M.; Radujkovic, M. 2013. The balanced scorecard and EFQM working together in a performance management framework in construction industry, Journal of Civil Engineering and Management 19(5): 683-695. http://dx.doi.org/10.3846/13923730.2013.799090

\section{Introduction}

The operational effectiveness in construction industry can be significantly improved by incorporating optimization into planning processes, i.e. strategic planning (Niven 2006; Klanšek, Pšunder 2010). Still, today only $5 \%$ of employees understand the company's strategy, only $25 \%$ of managers have initiatives closely tied to strategic priorities, only $40 \%$ of organizations link their budget with strategy and less than $15 \%$ of project teams spend even less than one hour on discussions about strategy (Johnson, Kaplan 1987; Kaplan, Lamotte 2001; Kaplan, Norton 2004, 2006). Practice has shown that regular use of performance management (PMM) models, i.e. EFQM Excellence model (EFQM) and the Balanced Scorecard (BSC), positively influences business results (Hoque, James 2000; Ahn 2001; McCabe 2001; Sandt et al. 2001; de Waal 2003; Bauer et al. 2004; Malina, Selto 2004; Radujkovic et al. 2010). As soon as Kaplan and
Norton (1992) introduced BSC it became a hit and showed its advantages over the other similar concepts. This was especially evident in the high strategic focus and the communication of strategic objectives throughout the organization. Furthermore, besides the traditionally criticized financial indicators (Beatham et al. 2004, 2005; Chan 2004; Halachmi 2005), BSC brought additional perspectives. Still the tool has been criticized for not being able to align strategy with competitive environment (Sinclair, Zairi 1995a, b, c; Kagioglou et al. 2001) nor conduct benchmarking (Vukomanović et al. 2008; French 2009a, b). EFQM, like BSC, is also well accepted in practice. Its strengths are encouraging continuous improvement through self-assessment and benchmarking (Cobbold, Lawrie 2002; de Waal, Counet 2006; Niven 2006). However, EFQM has also been criticized for its weak link with strategy and strategic integration process (Junnonen 1998). Despite the popularity of these two models, more than half of 
their implementations fail (Hakes 1995; Neely 2000, 2002; Bourne et al. 2003). Until now, many studies put EFQM and BSC on the opposite sides (Rusjan 2005; de Waal, Counet 2006; Dror 2008; de Waal 2008). Nevertheless, some authors suggested their integration into one unified system, but this has not been done yet (Andersen et al. 2000; Braam, Nijssen 2004; Bassioni et al. 2004; Beatham et al. 2004, 2005; Barad, Dror 2008; Yang 2009).

The aim of this study was to design a conceptual PMM framework that will improve BSC by adding a link with EFQM and thus introduce a new concept in managing performance in organizations. It will present Analytic Hierarchy Process (AHP) as the bridge between BSC and EFQM and show how it employs BSC and EFQM on a strategic level to control performance throughout the organization. The paper will show how the framework was designed and verified in the construction industry. At the end, the paper will discuss findings and give guidelines for implementing the framework in the practice.

\section{Literature review}

\subsection{Brief overview of PMM}

PMM is defined as the use of measurement results in order to achieve positive change in the organizational culture, business systems and processes, set agreed targets, allocate and rank resources, inform management about the need to change strategic objectives and to exchange performance results in order to stimulate continuous improvement of the system (Bassioni et al. 2004; Kerzner 2009). Over the years, the construction industry has mainly used three groups of PMM models: Key Performance Indicators (KPI)-based models, BSC-based models and EFQM-based models. Robinson et al. (2004) found that more than 50\% top companies in the UK use EFQM or BSC, $26.4 \%$ use different KPI models and only $22.8 \%$ companies do not use any of these models. Furthermore, $60 \%$ of The Fortune's TOP 1000 companies today use BSC (Niven 2006). The literature review showed a large amount of studies written on the topic of PMM, e.g. Hoque and James (2000) found the importance of nonfinancial performance in bank studies; Ahn (2001) stressed the importance of BSC for a strategic business unit; Sandt et al. (2001) explored manager satisfaction through Balanced Performance Measurement Systems and has found it highly applicable; de Waal and Counet (2006) gave lessons learned from BSC in public and private companies and discovered the model's deficiencies, especially in public sector; Bauer et al. (2004) comprehensively researched benchmarking of performance and listed applicable benchmarking models; Malina and Selto (2004) explored the selection process of performance measures and found a vast scarcity of literature, etc. Furthermore, during the last decade alone one paper was published every five hours in the working day (Neely 2002; Abudayyeh et al. 2004).

\subsection{The BSC}

Kaplan and Norton (1992) presented BSC in 1992 (see Fig. 1). The "balance" can be found in short-term and long-term objectives, as well as in quantitative and qualitative measures. Kaplan and Norton (2006) state that BSC supplements traditionally criticized financial indicators with indicators from the other three perspectives: investor/shareholders, clients, internal processes and learning and innovation. BSC possesses great strengths, e.g. safety from sub-optimization (it forces senior management to consider the majority of operational problems), it communicates strategy objectives throughout the organization and, if implemented correctly, generates only a small number of activities to control. It also identifies company's present state and future business potential and can be applied (so the authors claim) to both for-profit and not-for-profit organizations.

Over the years, BSC has received a large number of compliments from both industry and academia (The Harvard Business Review at the end of the millennium declared BSC to be "the most influential management idea in the past 75 years" (Niven 2006)). Nevertheless, the model has been criticized for over simplicity (Kagioglou et al. 2001) and for not covering all aspects of performance. Dror (2008) criticized the model for not having basic guidelines for selecting KPIs and complex feedback from the financial perspective to the other perspectives. Furthermore, Letza (1996) identified potential risks when implementing BSC: measuring the wrong things in the right way, presumption that some things could not be measured and conflict of functional managers within functional lines. Norreklit (2000) emphasized the questionability of a causal relationship between indicators. Papalexandris et al. (2005) noted that too little significance was given to critical success factors (strategic objectives) and that BSC was only designed for specific industries. Bontis et al. (1999) argued that the four perspectives were not universal and not sufficient. Kagioglou et al. (2001) later added two additional perspectives for the construction industry (project and sub-contractors perspectives). From its original form, BSC has evolved to a modern PMM model which now introduces new approaches, e.g. strategy maps, destination statements (DSs), etc. (known in the literature as the first, second and third generations of BSC (Andersen et al. 2000; Cobbold, Lawrie 2002)).

\subsection{EFQM}

EFQM was originally developed as a quality management system in 1991 (Hillman 1994) by the European 


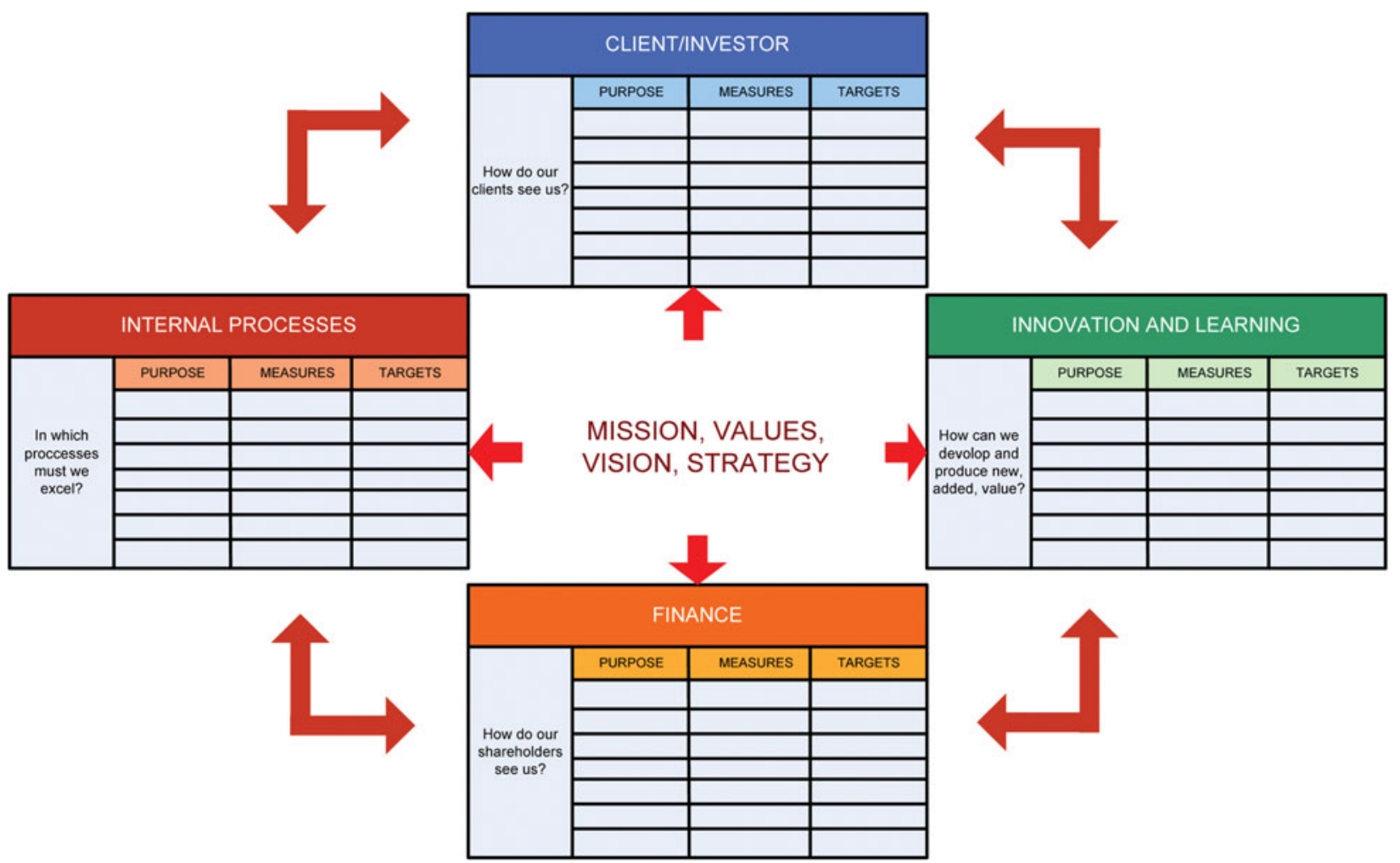

Fig. 1. The Balanced Scorecard (Kaplan, Norton 2005)

Foundation for Quality Management (now called just EFQM). The model is based on Total Quality Management (TQM) principles and has recently been advocated by many authors (e.g. Andersen et al. 2000; EFQM 2005; El-Mashaleh et al. 2007; de Waal 2008; Vukomanović et al. 2008). EFQM's purpose is to assess company's business excellence by identifying deviations of performance against the best practice and generating a stimulus in the form of improving activities (Beatham et al. 2004). EFQM assesses performance through the nine weighted criteria (see Fig. 2) and their respective sub-criteria. The model recognizes the distinction between lagging indicators (enablers) and leading indicators (results).
The model starts with leadership (the weight of $100-$ see Fig. 2) which afterwards leads to the other eight criteria. The client results have the highest impact on the final score $(20 \%)$, which shows strong TQM affiliation of the model (Kartha 2004; McAdam, Leonard 2005; Bou-Llusar et al. 2009). EFQM has become a very popular PMM tool in the construction (more than $60 \%$ of companies have implemented it (Andersen et al. 2000; Robinson et al. 2004). Nevertheless, the model has also received a great deal of criticism (Codling 1995; Andersen et al. 2000; McCabe 2001; Sharif 2002; Lam et al. 2004), mainly for not being able to focus and connect with strategy (Rusjan 2005).

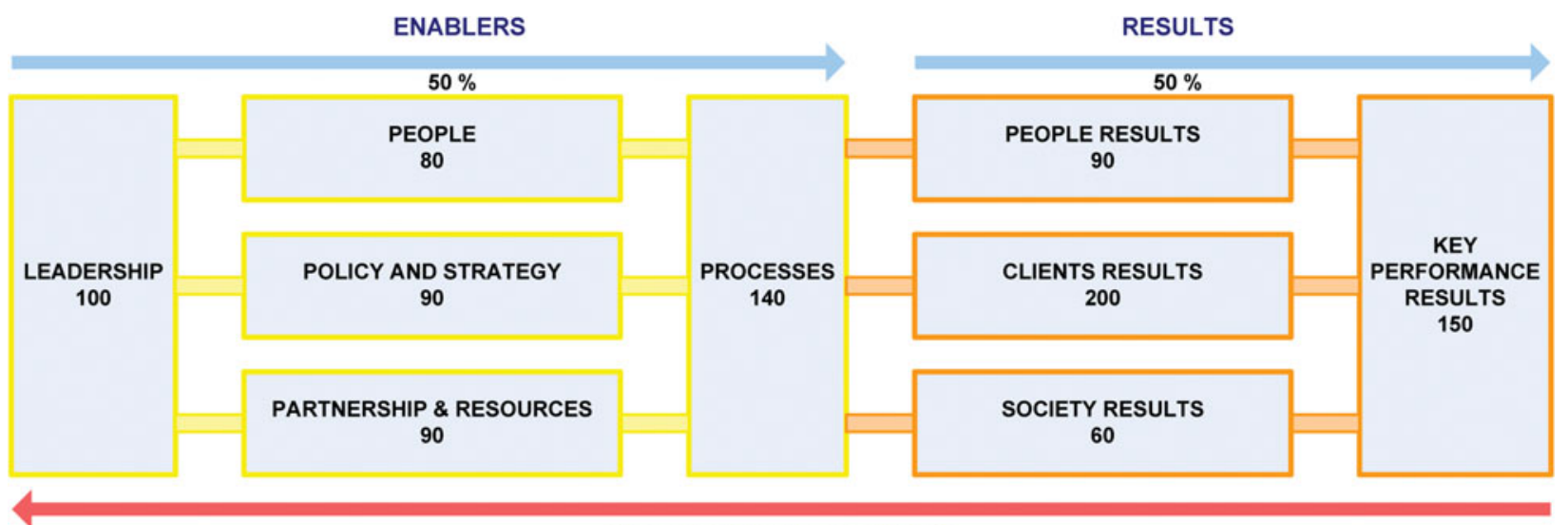




\subsection{BSC vs. EFQM}

To define differences and similarities between BSC and EFQM, one first has to understand various management control systems. There are generally three ways to control a management system using diagnostic control (DC), interactive control (IC) or strategic control (SC) (Simons 2000). DC works as a simple control of preset objectives, and is suitable for controlling implementation of the strategy. Its main characteristics are measurement of output from the system, setting the standards for future assessments and correcting deviations. DC is also known as the auto pilot, since organizations can use it to manage by exceptions (action is needed only if significant deviations have occurred).

IC focuses on strategic uncertainties, valorisation of strategy objectives and information used for strategy implementation (van Veen-Dirks, Wijn 2002). Its main characteristics are identifying strategic uncertainties, accepting feedback from operational managers and accepting frequent and regular feedback from managers at all levels. As opposed to DC (top-down approach), IC represents a bottom-up approach, where the need for strategic alignment arises from the lower levels of the organizations. Since these systems require a large amount of management time and energy, they can be applied only on few areas.

$\mathrm{SC}$ is the most advanced system. It constantly reexamines and reformulates strategy and can change with the competitive environment. SCs main characteristics are informing management about changes in the competitive surroundings, defining future opportunities, balancing between profits and investments, setting new and stretched objectives and constantly improving performance. Companies that implement SC are often described in literature as High Performance Organizations (de Waal 2008). SC is not a separate control, but a combination of DC and IC with constant alignment of strategy with the environment. The main reason for integrating BSC and EFQM is to initiate SC.

From the management control theory point of view, BSC and EFQM are two different concepts. BSC favours a clear focus on strategy and serves as the platform for other performance initiatives (e.g. EFQM). The model has dynamic design, since neither the criteria of performance assessment nor the selection of KPIs are predetermined. Therefore, BSC cannot be used for external benchmarking (competitive, industrial or generic). The model does not allow SC, but only DC or IC. Selection process of KPIs is vague and is also an obstacle to the model's efficiency, e.g. KPIs can be selected in respect to strategic objectives, and then, as the measurement process progresses, frequently adjusted. Consequently, BSC will signalize only when something goes wrong, i.e. when the expected finance performance has not been met and after substantial damage has already occurred (Mao et al. 2007). This shows how BSC easily isolates an organization from the environment and how it becomes a generator of lagging measures.

EFQM is prescriptive and based on a static design (just the opposite of BSC). It consists of a preset of standards and strategic objectives. The causal relationship between consequences and causes is only implicitly elaborated. Companies will find EFQM much easier to use than BSC, since the methodology of self-assessment is prescribed (Lawrie et al. 2004). EFQM maintains the relationship with the environment and can signalize which business processes are (or not) aligned with changes in the competitive environment (external benchmarking).

On one hand, the greatest strength of EFQM over BSC is its ability to conduct benchmarking but on the other, the greatest weakness is the loss of the strategic focus. Table 1 shows for which processes

Table 1. Selecting the most appropriate model for different management requirements

Goal Model

To align strategic priorities with mission and vision BSC

To set priorities within strategic objectives

To align operations, activities and processes with strategic priorities

To stimulate communication of strategy throughout the organization on different levels

To divert management from financial analysis on to future demands and issues process

To communicate problems from operational levels to top management

To initiate diagnostic or interactive control

To check if measurement is being conducted properly

To implement benchmarking in industry or a generic level

BSC

To identify best practice

To assess the organization's performance and identify areas of improvement

BSC

BSC

To initiate the process of constant improvement

To align targets and objectives in accordance with the competitive environment

To check if the right areas are being measured

BSC

BSC

BSC 
management should use BSC or EFQM, e.g. if an organization wants to align activities with mission and vision - it should use BSC, and if it wants to assess organizational performance it should use EFQM. When the strengths of the two models are put together, it is clear how BSC and EFQM are complementary tools and that $\mathrm{EFQM}$ is the missing link of SC by BSC.

\section{The methodology of developing the framework}

The framework was designed during EFQM selfassessment of 34 construction companies in Croatia. The companies were all from the construction, where $16 \%$ were investors (client, sponsor), $52 \%$ were consultants (designers, supervision, surveyors, project managers, etc.) and $32 \%$ were contractors. In terms of size by employee $32 \%$ had $>250,15 \%$ had $50-250$, $20 \%$ had $10-50$ and $33 \%$ had $<10$. After the framework had been developed, it was verified in a construction company in Croatia. The framework was developed in two phases: (1) development and (2) verification.

The framework (Fig. 3), balances between inner (BSC) and outer performance (EFQM) of an organization, where:

- BSC is used to identify strategic priorities, communicate the strategy within the organization, enable DC by pressuring strategic objectives on to the lower levels, enable IC by discovering new initiatives at lower levels and check whether the organization has achieved strategic goals.

- EFQM is used to check the strategic alignment with the environment by benchmarking and finding areas for improvement in the strategy of an organization.

While trying to integrate BSC and EFQM, we found AHP as the most suitable method. AHP (Saaty 1980) is a decision-making tool, based on the Eigen value approach to pair-wise comparisons of multiple criteria. AHP has become highly popular within academia and has a strong positive trend in use (Vaidya, Kumar 2006). The method has been used in a wide variety of areas, including resource allocation, public policy (Shahin, Mahbod 2007), strategic planning of organizational resources (Saaty 1990), the evaluation of strategic alternatives (Tavana, Banerjee 1995), etc. Yet, only a small number of studies have used AHP for selecting KPIs (Shahin, Mahbod 2007).

We also considered similar tools, e.g. SMART (van Veen-Dirks, Wijn 2002), PROMETHE (Brans et al. 1986), ANP (Saaty 1996), etc. But we selected AHP, owning to its high popularity and validated use in practice and since it comes with Expert Choice (software for overcoming the complexity of the method). AHP was used twice: once when setting priorities for strategic objectives and once when

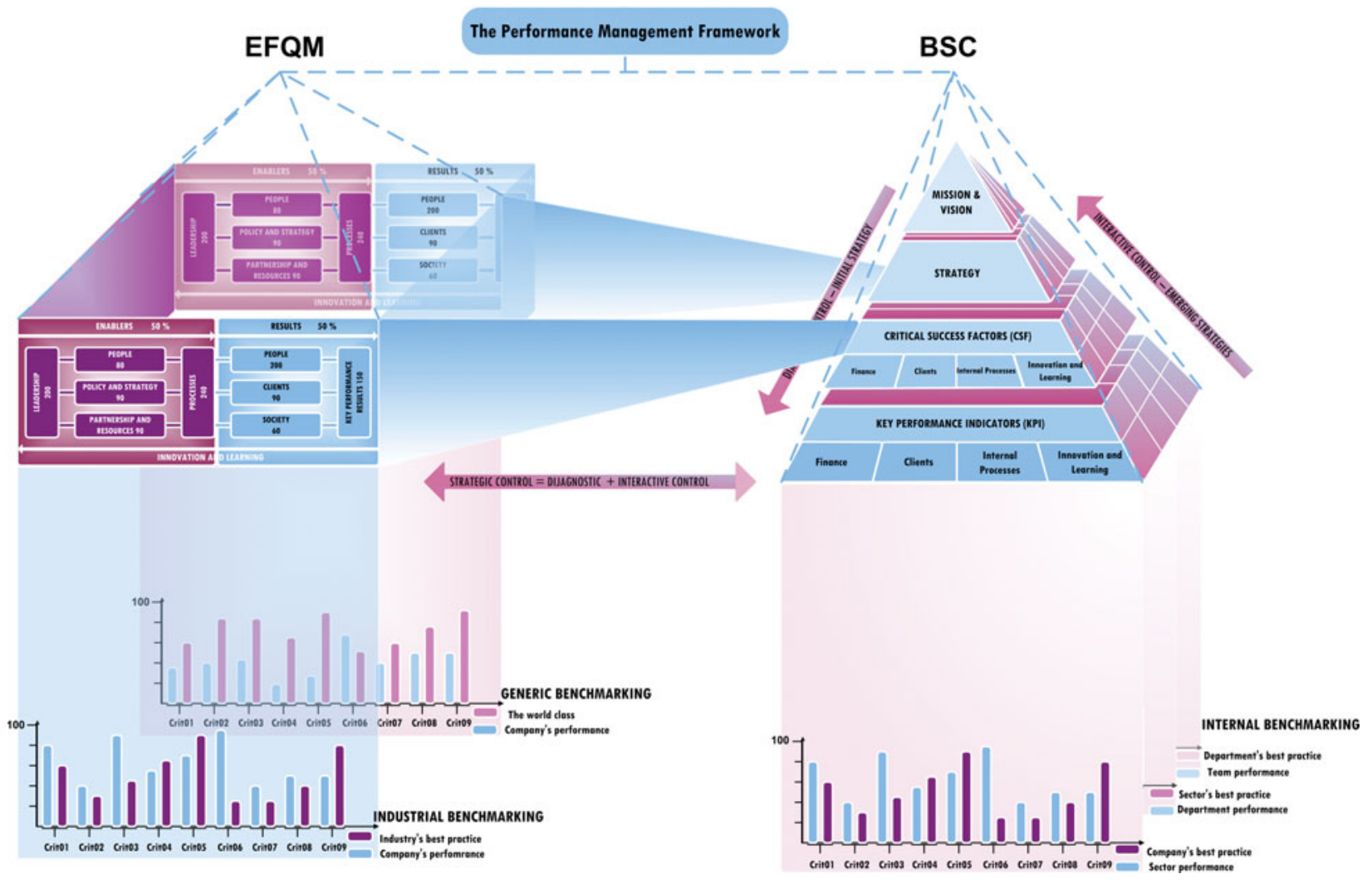

Fig. 3. The two sides of the performance management framework 
setting priorities for KPIs within the perspectives of BSC. For the first AHP model (Fig. 4, step 3), EFQM criteria were used as the AHP criteria for selecting strategic objectives. Their pair-wise ponders are calculated as discrepancies of performance between best practice and the performance of the observed company (EFQM score). AHP then lists the strategic objectives in ranked order. The ranks were afterwards assigned to a strategy map. Consequently, the strategic objectives with lower rank were discarded from the initial map. For every strategic objective (Fig. 4, step 8), KPIs were selected against SMARTER criteria (Specific, Measurable Achievable, Relevant, Time-bound, Extended/Exciting and Rewarding/Recorded). Shahin and Mahbod (2007) have already developed similar model but with SMART criteria. We added ' $E$ ' and ' $R$ ' since extended goals and rewards have proved to be simulative incentives of implementing strategy (Beatham et al. 2004, 2005).

Radar $^{\mathrm{TM}}$ control (Fig. 5, cycle 1) was originally developed by EFQM as the controlling mechanism of the Excellence model. It comprised four stages: $R$ (determine Results required), A (plan and develop Approaches), D (Deploy approaches) and AR (Assess and Review approaches). This framework relies on RADAR rationale, but in an extended form (three cycles of control, instead of one Radar cycle, see Fig. 5). The two first cycles are used for BSC and the third cycle for EFQM. The first cycle employs a basic DC, which involves identifying strategic objectives and KPIs from the strategy (see Concept and Planning and Approach in Fig. 5). After the initial measurement (see Implementation in Fig. 5), the system controls whether the planned values have been met (see Review and Assessment in Fig. 5). If they have, the system sets new stretched goals, and if not, it tries to minimize the deviation in forthcoming measurements. The second cycle enables IC by adding two additional components (see Concept 2 and Planning and Approach 2 in Fig. 5) to steps 3 and 4 from the first cycle (see Implementation and Review and Assessment in Fig. 5). In Concept 2, companies re-question strategic objectives and identify strategic uncertainties. If the areas of improvement have been met, new and improved targets for organization development (see Planning and approach 2 in Fig. 5) are set (see Implementation in Fig. 5) and controlled (Review and Assessment in Fig. 5). In the third, optional, cycle, strategic objectives are reviewed and reassessed in respect to the periodical benchmarking scores (EFQM assessment across the industry). Thus, strategic objectives are externally re-evaluated and, if needed, aligned with the environment.

\section{Verification of the framework}

This section will show how the framework was verified in a construction company in Croatia (during the period June 2009-December 2010) through 10 steps
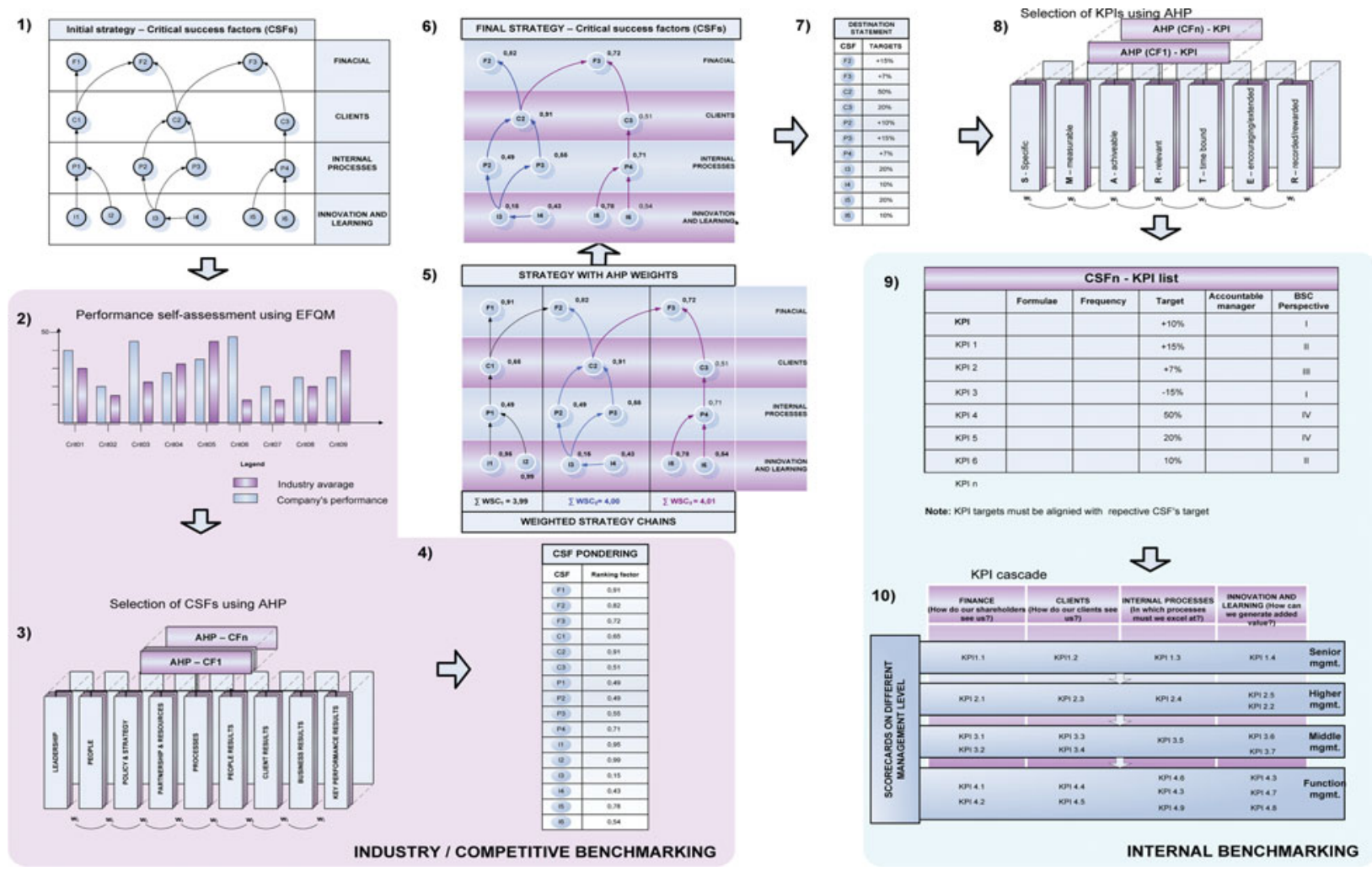

Fig. 4. The verification of the framework through 10 steps 


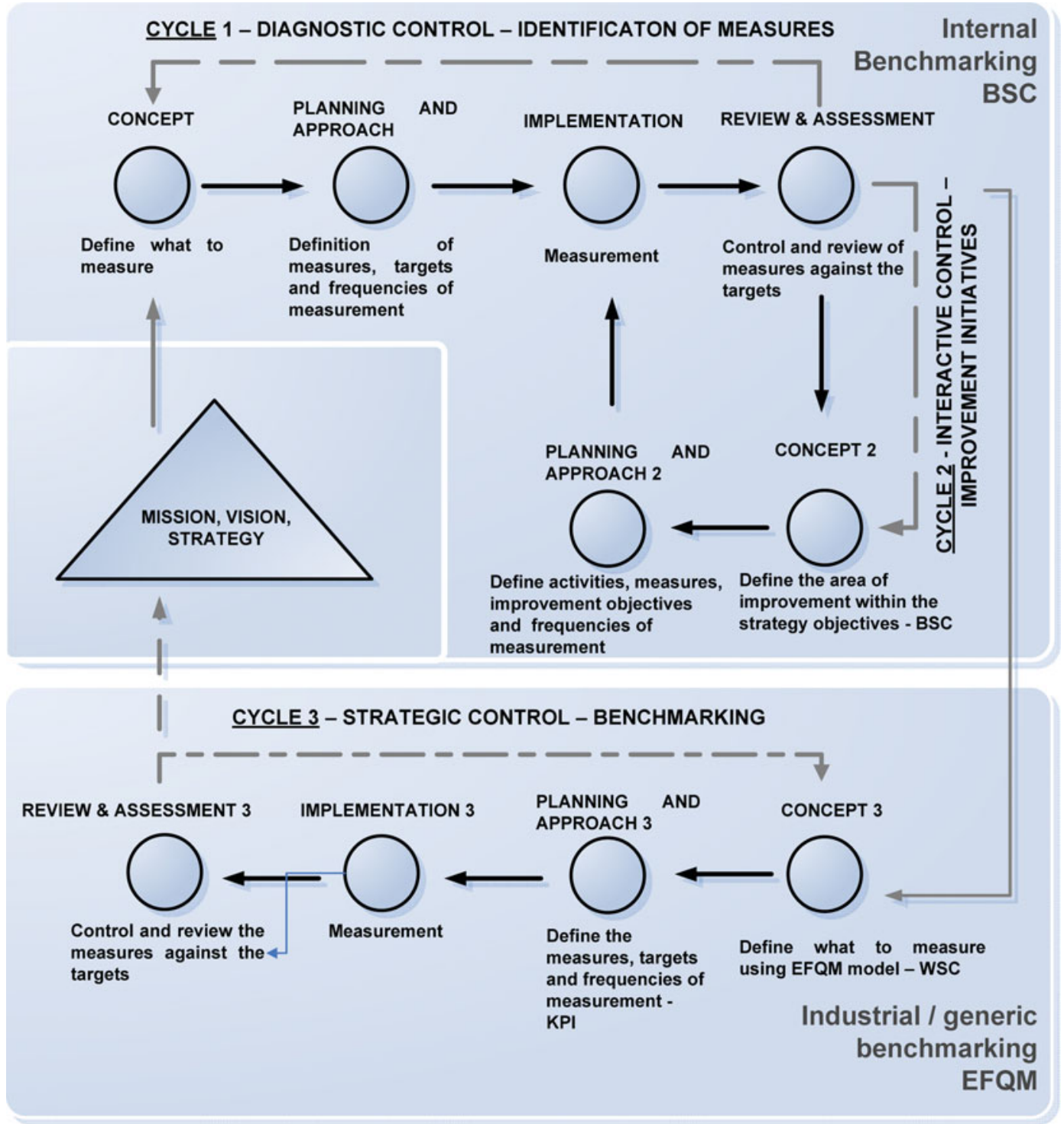

\section{LEGEND:}

Fig. 5. The three cycles of the monitoring and control process

(Fig. 4). We will not elaborate these steps extensively because of the brevity of the paper.

STEP 1: Initial strategy. At the beginning we mapped strategic objectives (see Fig. 4, step 1) and thus delineated the logic of strategic thinking. This was done as follows. First, lagging measures were identified at the highest level (the finance perspective) and linked to the lowest levels (the innovation and learning perspective). Second, for each lagging measure, leading measures were identified. Afterwards, the measures were distributed into the four perspectives of BSC. Figure 4 shows how specific groups of strategic objectives contribute to the same cause (see Fig. 4, I1, I2, P1 C1 and
F1). One objective can also contribute to several other groups (e.g. C2, see Fig. 4). These strategic groups were named as the Weighted Strategy Chains (WSC).

STEP 2: Performance self-assessment using $E F Q M$. During step 2 (see Fig. 4, step 2) we conducted EFQM assessment of the construction industry in Croatia. In total, 34 construction companies were assessed (the demographics are given in Section 3); yielding the best practice (we will not elaborate either the self-assessment process or the sample specifics in detail because of the brevity of the paper). The discrepancies between the company and best practice are shown in Table 2. 
STEP 3: Selection of strategic objectives using $A H P$. In step 3, all of the strategic objectives were processed through the AHP model, based on EFQM criteria. Table 3 shows the performance ratios between best practice and the observed company for every EFQM criterion. AHP pair-wise weights $\left(w_{i}\right)$ were calculated using Eqn. (1). Table 4 shows the AHP matrix with final pair-wise ratios. Altogether, four

Table 2. Comparison between best practice and the observed company

\begin{tabular}{lcc}
\hline & $\begin{array}{c}\text { Best practice of the } \\
\text { Croatian construction } \\
\text { industry }\end{array}$ & $\begin{array}{c}\text { The observed } \\
\text { company }\end{array}$ \\
\hline (1) Leadership & 64 & 16 \\
(2) Policy and & 65 & 5 \\
strategy & & \\
(3) People & 72 & 24 \\
(4) Partnership & 84 & 43 \\
and resources & & \\
(5) Processes & 117 & 59 \\
(6) Client results & 125 & 46 \\
(7) People results & 45 & 21 \\
(8) Society results & 42 & 34 \\
(9) Key & 113 & \\
performance & & \\
results & & \\
\hline
\end{tabular}

Table 3. Ratio of best practice and the performance of the observed company

\begin{tabular}{lr}
\hline Enablers & $x_{i}$ \\
\hline (1) Leadership & 4.00 \\
(2) Policy and strategy & 13.00 \\
(3) People & 3.00 \\
(4) Partnership and resources & 1.95 \\
(5) Processes & 1.98 \\
Results & $y_{i}$ \\
(6) Client results & 2.72 \\
(7) People results & 22.50 \\
(8) Society results & 2.00 \\
(9) Key performance results & 3.32 \\
\hline
\end{tabular}

different matrixes were run (one for each BSC perspective):

$$
a=\frac{b_{i}}{c_{j}}, i, j=1,9,
$$

where: $a$ - weight of a EFQM criterion; $b-$ performance of a best practice criterion; $c$ - performance of a EFQM criterion of the observed company.

STEP 4: Pondering of strategic objectives. Consequently, the AHP matrix from step 3 produced a listing of strategic objectives. Table 5 shows only the top 10 strategic objectives (the pilot produced a list of more than 40 strategic objectives). These steps thus allowed the company to implement industrial benchmarking and align the strategy with the environment.

STEP 5: Weighted strategy chains. In step 5, weights were assigned to strategic objectives in the initial strategy map. Figure 4 shows how every strategic path (or chain) in the strategy map can provide a final sum for a particular strategy chain.

STEP 6: Final strategy. For an effective strategy, there should be only $8-12$ areas of strategic improvement (Cobbold, Lawrie 2002). Therefore, in this step we discarded less important strategic objectives from the initial strategy map and thus identified the critical areas of improvement.

STEP 7: DS. DS besides having high motivational effect, increases success of BSC (Lawrie et al. 2004; Robinson et al. 2004). The scorecards that incorporate DS are often called a third generation BSC. The targets were set by the management alone, where we did not have any influence.

STEP 8: Selection of KPIs using AHP. This step also employed AHP but for selecting most suitable KPIs for every strategic objective. KPIs were ranked against seven SMARTER criteria. The weights of pair-wise comparison were preset by the management (see Table 6). Some of the strategic objectives needed no use of this model since there was only one possible KPI (e.g. client satisfaction, which has a standardized questionnaire survey at every level). Still, in situations where the management had been dwelling on different KPIs for a particular strategic objective, this step had

Table 4. Pair-wise weights for the AHP model for selecting strategic objectives

\begin{tabular}{|c|c|c|c|c|c|}
\hline Enablers $\left(a_{i j}\right)$ & Leadership & Policy and strategy & Employees & Partnership and resources & Processes \\
\hline Leadership & 1.00 & 0.31 & 1.33 & 2.05 & 2.02 \\
\hline Policy and strategy & & 1.00 & 4.33 & 6.65 & 6.56 \\
\hline Employees & & & 1.00 & 1.54 & 1.51 \\
\hline Partnership and resources & & & & 1.00 & 0.99 \\
\hline Processes & & & & & 1.00 \\
\hline Results $\left(b_{i j}\right)$ & Client results & People results & Society results & \multicolumn{2}{|c|}{ Key performance results } \\
\hline Client results & 1.00 & 0.12 & 1.36 & \multicolumn{2}{|l|}{0.82} \\
\hline People results & & 1.00 & 11.25 & \multicolumn{2}{|l|}{6.77} \\
\hline Society results & & & 1.00 & \multicolumn{2}{|l|}{0.60} \\
\hline Key performance results & & & & \multicolumn{2}{|l|}{1.00} \\
\hline
\end{tabular}


Table 5. Pair-wise weights for the AHP model for selecting strategic objectives

\begin{tabular}{llc}
\hline Strategic objectives & $\begin{array}{c}\text { Priority } \\
\text { (from AHP) }\end{array}$ \\
\hline (1) & Separate ownership from management & 0.910 \\
(2) & Define assignments for manager & 0.861 \\
(3) & Introduce personal development plans & 0.769 \\
(4) & Decrease costs & 0.779 \\
(5) & Recruit highly educated employees & 0.746 \\
(6) & Introduce rewarding policy & 0.709 \\
(7) & Introduce project oriented policy & 0.634 \\
(8) & Define business policy & 0.619 \\
(9) & Develop project management standard & 0.614 \\
(10) & Improve control of sub-contractors & 0.551 \\
\hline
\end{tabular}

Table 6. Weights given to a particular criterion for KPI selection

\begin{tabular}{lcr}
\hline KPI criteria & $s$ & $\%$ \\
\hline S & 0.10 & 10 \\
M & 0.15 & 15 \\
A & 0.15 & 15 \\
R & 0.10 & 10 \\
T & 0.10 & 10 \\
E & 0.20 & 20 \\
R & 0.20 & 20 \\
SUM & 1.00 & 100 \\
\hline
\end{tabular}

to be undertaken. Here we assigned the senior and middle management a task to grade KPIs against SMARTER criteria. After the KPI's were graded, Eqn. (2) was used to calculate pair-wise comparisons (see Table 7) and generate final list of ranked KPIs:

$$
t_{i j}=\frac{s_{j}}{s_{i}}, i, j=1,7,
$$

where: $t_{i j}$ - the weight of a criterion for KPI selection; $s$ - the weight given to one of the SMARTER criteria.

STEP 9: KPI list. After the KPIs were ranked, they were assigned within their respective BSC perspective. We kept the total number of KPIs up 25 measures (Kaplan, Norton 2006, 2008). Every KPI was defined by Name, Formulae, Target, Accountable manager and BSC perspective.

Table 7. Pair-wise weights for the AHP model for selecting KPIs

\begin{tabular}{lccccccc}
\hline$t_{i j}$ & $\mathrm{~S}$ & $\mathrm{M}$ & $\mathrm{A}$ & $\mathrm{R}$ & $\mathrm{T}$ & $\mathrm{E}$ & $\mathrm{R}$ \\
\hline $\mathrm{S}$ & 1.00 & 0.67 & 0.67 & 1.00 & 1.00 & 0.50 & 0.50 \\
$\mathrm{M}$ & & 1.00 & 1.00 & 1.50 & 1.50 & 0.75 & 0.75 \\
$\mathrm{~A}$ & & & 1.00 & 1.50 & 1.50 & 0.75 & 0.75 \\
$\mathrm{R}$ & & & & 1.00 & 1.00 & 0.50 & 0.50 \\
$\mathrm{~T}$ & & & & & 1.00 & 0.50 & 0.50 \\
$\mathrm{E}$ & & & & & & 1.00 & 1.00 \\
$\mathrm{R}$ & & & & & & & 1.00 \\
\hline
\end{tabular}

STEP 10: KPI cascade. The last step was to communicate KPIs from the highest on to the lowest management levels. In this cascade of indicators, every lower level had its own scorecard developed, where KPIs were closely tied with higher objectives. This step allowed the company to implement internal benchmarking between different hierarchy levels or different sectors.

\section{Discussion}

This framework has showed how BSC, if integrated with EFQM, can go beyond its original capabilities and how it can enable SC and conduct benchmarking in the fast changing environment. This is important to acknowledge, since BSC will easily become the generator of lagging measures if there is no formal link with the environment. This study has also showed that EFQM and BSC are complementary tools, where the BSC's strengths (Fig. 6) are at the same time the weaknesses of EFQM, and vice versa, and how only by joining the two, an organization can use the right indicators - properly. This challenges many studies that have suggested just the opposite (Cobbold, Lawrie 2002; Lawrie et al. 2004; Dror 2008). In fact, EFQM is the missing link for conducting SC with BSC.

The framework employs EFQM for external benchmarking and BSC for DC and IC. Even though Kaplan and Norton (2008) concluded that for efficient performance control, companies must have the four perspectives in balance, the framework goes even further and balances between both business opportunities and threats (EFQM) and implementation of strategy (BSC). However, even though EFQM is proclaimed to be a great benchmarking tool, we have found the tool inapplicable for public construction companies in transitional economies (e.g. in Croatia). This was because many public organizations in Croatia had developed neither a clear mission nor vision nor strategy. We verified the framework in a construction company. The framework identified strategic objectives within BSC perspectives, in regard with EFQM benchmarking scores. The ranking criteria of the strategic objectives (the AHP pair-wise ratios) were calculated as the ratios of best practice and performance of selected company, which afterwards yielded a listing of ranked strategic objectives. This was the critical point in developing the framework, where EFQM served as an early warning system for BSC and where it initiated SC.

This framework brings another improvement (the second AHP model for selecting KPIs within BSC) a novel model, which solves one of the main weaknesses of BSC, i.e. of not having a KPI selection method.

The framework's control system has three cycle closed-loop architecture, comprising DC (setting KPI goals), IC (setting rewarding and exciting goals) and SC (aligning strategy with benchmarking scores). 


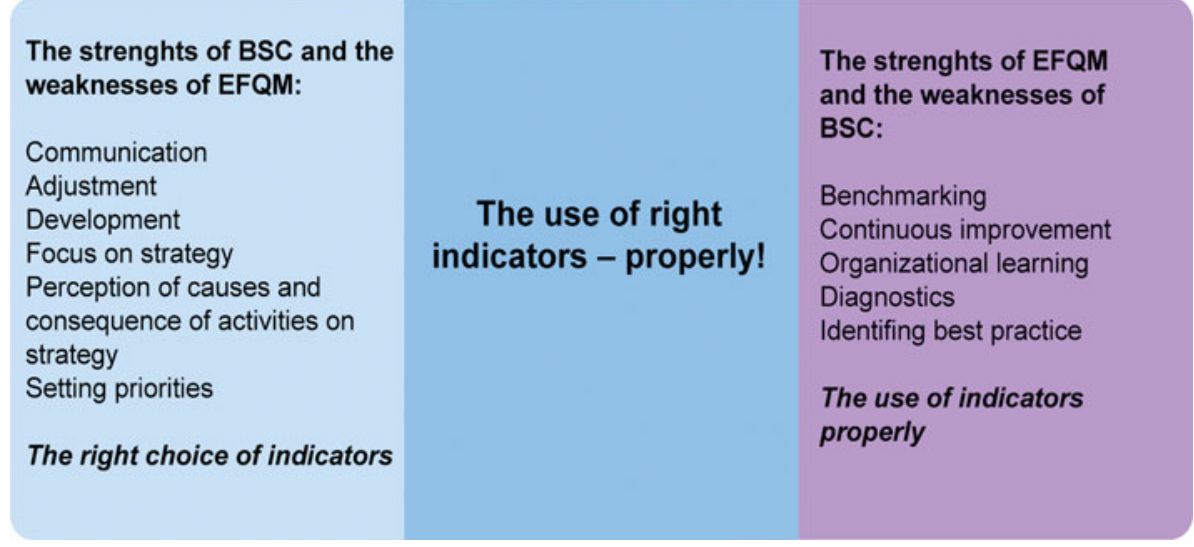

Fig. 6. Benefits of the framework

Therefore, this framework measures, re-evaluates and finally re-controls strategic objectives thus enables SC.

This study also has certain limitations that need to be addressed. First, similar integrations were already conducted. Thus, van Veen-Dirks and Wijin (2002), instead of joining BSC and EFQM, put BSC and Critical Success Factors together and Yang (2009) integrated EFQM with Malcolm Baldrige National Quality Award (MBNQA). Second, the scope of this study did not include project level performance nor did it try to evaluate the framework's influence on organizational performance, or the efficiency of these initiatives on overall management processes. Third, the model was not validated on a larger population and therefore its wider applicability in practice should be further researched. The integration was part of a pilot study where our team had full commitment of senior management. In reality, we believe the integrated framework of BSC and EFQM may require substantial effects in administration. Fourth, this study did not try to discover the best way of forming an effective mission, vision or strategy nor did it try to find the best way to identify strategic objectives or KPIs, but only to prioritize them.

\section{Conclusions}

Globalization is inevitably advancing and today there are no stable markets. This effect is also present in the construction industry. Companies that were using BSC and EFQM in stable markets now have stepped into an unstable environment and become very convinced of the drawbacks that can occur (Hoque, James 2000; Foster 2001; van Veen-Dirks, Wijn 2002). Therefore, current PMM models, i.e. BSC and EFQM, should be upgraded into a modern $\mathrm{SC}$ system.

This paper has described how BSC and EFQM can be successfully joined together and how the integration can enable companies to conduct benchmarking, prioritize strategic objectives in respect to their competitors and prioritize, select the most efficient KPIs for every strategic objective and initiate SC.
Therefore, by implementing this framework, companies can control implementation of the strategy and simultaneously evaluate the strategy within a larger context. Companies willing to use this framework should keep in mind the following guidelines.

Vision and strategy should serve as input for the system:

1) The strategy should be mapped in the four perspectives of BSC.

2) Strategic objectives have to be aligned with the environment (EFQM benchmarking).

3) Every strategic objective ought to have at least one KPI assigned.

4) KPIs have to be cascaded down on to lower management levels.

5) Besides DC, management should select areas that will be controlled interactively.

6) Organizational performance has to be periodically benchmarked and strategy re-evaluated and realigned with best practice.

Furthermore, companies from other industries besides the construction are encouraged and welcomed to use this framework, but with the proviso that they must align it to their specific needs.

In future research a comparison of different decision-making frameworks (such as Prometheus, Electra or Smart) with AHP should be conducted to discover the most efficient multicriteria decision tool for integrating BSC and EFQM. We strongly encourage such research activities in order to form even better PMM model and thus help companies in achieving excellence.

\section{References}

Abudayyeh, O.; Dibert-DeYoung, A.; Jaselskis, E. 2004. Analysis of trends in construction research: 19852002, Journal of Construction Engineering and Management ASCE 130(3): 433-439. http://dx.doi.org/10.1061/(ASCE)0733-9364(2004)130: $3(433)$ 
Ahn, H. 2001. Applying the balanced scorecard concept: an experience report, Long Range Planning 34(4): 441461.

http://dx.doi.org/10.1016/S0024-6301(01)00057-7

Andersen, H.; Lawrie, G.; Shulver, M. 2000. The balanced scorecard vs. the EFQM business excellence model: Which is the better strategic management tool? 2GC Active Management White paper.

Barad, M.; Dror, S. 2008. Strategy maps as improvement paths of enterprises, International Journal of Production Research 46(23): 6627-6647. http://dx.doi.org/10.1080/00207540802230405

Bassioni, H.; Price, A.; Hassan, T. 2004. Performance measurement in construction, Journal of Management in Engineering 20(2): 42-50.

http://dx.doi.org/10.1061/(ASCE)0742-597X(2004)20: 2(42)

Bauer, J.; Tanner, S.; Neely, A. 2004. Benchmarking performance measurement: a consortium benchmarking study. Performance measurement and management: public and private. Cranfield: Cranfield University, Cranfield, Centre for Business Performance.

Beatham, S.; Anumba, C.; Thorpe, T.; Hedges, I. 2004. KPIs: a critical appraisal of their use in construction, Benchmarking: an International Journal 11(1): 93-117. http://dx.doi.org/10.1108/14635770410520320

Beatham, S.; Anumba, C.; Thorpe, T.; Hedges, I. 2005. An integrated business improvement system (IBIS) for construction, Measuring Business Excellence 9(2): 42-55. http://dx.doi.org/10.1108/13683040510602876

Bontis, N.; Dragonetti, N.; Jacobsen, K.; Roos, G. 1999. The knowledge toolbox: a review of the tools available to measure and manage intangible resources, European Management Journal 17(4): 391-402. http://dx.doi.org/10.1016/S0263-2373(99)00019-5

Bou-Llusar, J. C.; Escrig-Tena, A. B.; Roca-Puig, V.; Beltrán-Martín, I. 2009. An empirical assessment of the EFQM excellence model: Evaluation as a TQM framework relative to the MBNQA model, Journal of Operations Management 27(1): 1-22. http://dx.doi.org/10.1016/j.jom.2008.04.001

Bourne, M.; Neely, A.; Mills, J.; Platts, K. 2003. Implementing performance measurement systems: a literature review, International Journal of Business Performance Management 5(1): 1-24. http://dx.doi.org/10.1504/IJBPM.2003.002097

Braam, G.; Nijssen, E. 2004. Performance effects of using the balanced scorecard: a note on the Dutch experience, Long Range Planning 37(4): 335-349. http://dx.doi.org/10.1016/j.1rp.2004.04.007

Brans, J. P.; Vincke, P.; Mareschal, B. 1986. How to select and how to rank projects: the PROMETHEE method, European Journal of Operational Research 24(2): $228-238$.

http://dx.doi.org/10.1016/0377-2217(86)90044-5

Chan, A. 2004. Key performance indicators for measuring construction success, Benchmarking: an International Journal 11(2): 203-221.

http://dx.doi.org/10.1108/14635770410532624
Cobbold, I.; Lawrie, G. 2002. The development of the balanced scorecard as a strategic management tool. Performance Measurement Association White paper. University of Cambridge.

Codling, S. 1995. Best practice benchmarking. Brookfield, VT, USA: Gower. 153 p.

de Waal, A. 2003. Behavioural factors important for the successful implementation and use of performance management systems, Management Decision 41(8): 688-697. http://dx.doi.org/10.1108/00251740310496206

de Waal, A. 2008. The secret of high performance organizations. Management Online Review [online], [cited 10 October 2011]. Available from Internet: http://www.hpocenter.nl/uploads/MORE\%20-\%20The $\% 20$ Secret $\% 20$ of $\% 20$ HPOs $\% 20-\% 20$ April2008.pdf.

de Waal, A.; Counet, H. 2006. Lessons learned from the balanced scorecard. Performance measurement and management: Public and private. Cranfield: Cranfield School of Management.

Dror, S. 2008. The balanced scorecard versus quality award models as strategic frameworks, Total Quality Management \& Business Excellence 19(6): 583-593. http://dx.doi.org/10.1080/14783360802024366

EFQM. 1999. Excellence model. Brussels: EFQM Publishing.

EFQM. 2005. Radarise your business for success. Brussels: EFQM Publishing.

El-Mashaleh, M.; Minchin Jr, R.; O’Brien, W. 2007. Management of construction firm performance using benchmarking, Journal of Management in Engineering 23(1): 10-18.

http://dx.doi.org/10.1061/(ASCE)0742-597X(2007)23: $1(10)$

Foster, R. N. 2001. Creative destruction: why companies that are built to last underperform the market and how to successfully transform them. Extreme competition. New York: McKinsey Quarterly.

French, S. 2009a. Critiquing the language of strategic management, Journal of Management Development 28(1): 6-17. http://dx.doi.org/10.1108/02621710910923836

French, S. 2009b. Re-thinking the foundations of the strategic business process, Journal of Management Development 28(1): 51-76. http://dx.doi.org/10.1108/02621710910923863

Hakes, C. 1995. The corporate self assessment handbook for measuring business excellence. New York: Chapman \& Hall. 205 p.

Halachmi, A. 2005. Performance measurement is only one way of managing performance, International Journal of Productivity and Performance Management 54(7): 502-516. http://dx.doi.org/10.1108/17410400510622197

Hillman, G. 1994. Making self-assessment successful, The TQM Magazine 6(3): 29-31. http://dx.doi.org/10.1108/09544789410057863

Hoque, Z.; James, W. 2000. Linking balanced scorecard measures to size and market factors: impact on organizational performance, Journal of Management Accounting Research 12(1): 1-17. http://dx.doi.org/10.2308/jmar.2000.12.1.1 
Johnson, H.; Kaplan, R. 1987. Relevance lost: the rise and fall of management accounting. Boston: Harvard Business School Press. 273 p.

Junnonen, J. 1998. Strategy formation in construction firms, Engineering, Construction and Architectural Management 5(2): 107-114. http://dx.doi.org/10.1108/eb021065

Kagioglou, M.; Cooper, R.; Aouad, G. 2001. Performance management in construction: a conceptual framework, Construction Management and Economics 19(1): 85-95. http://dx.doi.org/10.1080/01446190010003425

Kaplan, R.; Lamotte, G. 2001. The balanced scorecard and quality programs, Balanced Scorecard Report 3(2): 9-13.

Kaplan, R.; Norton, D. 1992. The balanced scorecard: Measures that drive performance, Harvard Business Review 70(1): 71-79.

Kaplan, R.; Norton, D. 2004. Strategy maps: converting intangible assets into tangible outcomes. Boston: Harvard Business School Press. 457 p.

Kaplan, R.; Norton, D. 2005. The balanced scorecard: measures that drive performance, Harvard Business Review 83(7): 172-180.

Kaplan, R.; Norton, D. 2006. Alignment: using the balanced scorecard to create corporate synergies. Boston: Harvard Business School Press. 403 p.

Kaplan, R.; Norton, D. 2008. Mastering the management system, Harvard Business Review 86(1): 62-67.

Kartha, C. 2004. A comparison of ISO 9000: 2000 quality system standards, QS9000, ISO/TS 16949 and Baldrige criteria, The TQM Magazine 16(5): 331-340. http://dx.doi.org/10.1108/09544780410551269

Kerzner, H. 2009. Project management: a systems approach to planning, scheduling, and controlling. New Jersey: Wiley. $1065 \mathrm{p}$.

Klanšek, U.; Pšunder, M. 2010. Cost optimization of the time schedule for project management, Ekonomska istrazivanja [Economic Research] 23(4): 22-36.

Lam, E.; Chan, A.; Chan, D. 2004. Benchmarking design-build procurement systems in construction, Benchmarking: an International Journal 11(3): 287-302.

http://dx.doi.org/10.1108/14635770410538763

Lawrie, G.; Cobbold, I.; Marshall, J. 2004. Corporate performance management system in a devolved UK governmental organisation: a case study, International Journal of Productivity and Performance Management 53(4): 353-370.

http://dx.doi.org/10.1108/17410400410533926

Letza, S. 1996. The design and implementation of the balanced business scorecard, Business Process Reengineering and Management Journal 2(3): 54-76. http://dx.doi.org/10.1108/14637159610151217

Malina, M.; Selto, F. 2004. Choice and change of measures in performance measurement models, Management Accounting Research 15(4): 441-469. http://dx.doi.org/10.1016/j.mar.2004.08.002

Mao, W.; Zhu, Y.; Ahmad, I. 2007. Applying metadata models to unstructured content of construction documents: a view-based approach, Automation in
Construction 16(2): 242-252.

http://dx.doi.org/10.1016/j.autcon.2006.05.005

McAdam, R.; Leonard, D. 2005. A TQM dynamics perspective on Baldrige and business excellence model comparisons, Total Quality Management \& Business Excellence 16(6): 771-791. http://dx.doi.org/10.1080/14783360500077757

McCabe, S. 2001. Benchmarking in construction. Oxford: Blackwell Publishing. 291 p.

Neely, A. 2000. Three modes of measurement: theory and practice, International Journal of Business Performance Management 1(1): 47-64. http://dx.doi.org/10.1504/IJBPM.1998.004544

Neely, A. 2002. Business performance measurement: theory and practice. Cambridge: Cambridge University Press. $369 \mathrm{p}$.

Niven, P. 2006. Balanced scorecard step-by-step: maximizing performance and maintaining results. New York: Wiley. $327 \mathrm{p}$.

Norreklit, H. 2000. The balance on the balanced scorecard a critical analysis of some of its assumptions, Management Accounting Research 11(1): 65-88.

http://dx.doi.org/10.1006/mare.1999.0121

Papalexandris, A.; Ioannou, G.; Prastacos, G.; Eric Soderquist, K. 2005. An integrated methodology for putting the balanced scorecard into action, European Management Journal 23(2): 214-227.

http://dx.doi.org/10.1016/j.emj.2005.02.004

Radujkovic, M.; Vukomanovic, M.; Dunovic, I. B. 2010. Application of key performance indicators in South Eastern European construction, Journal of Civil Engineering and Management 16(4): 521-530. http://dx.doi.org/10.3846/jcem.2010.58

Robinson, H.; Anumba, C.; Carrillo, P.; Al-Ghassani, A. 2004. Business performance measurement practices in construction engineering organizations, Measuring Business Excellence 9(1): 13-22. http://dx.doi.org/10.1108/13683040510588800

Rusjan, B. 2005. Usefulness of the EFQM excellence model: theoretical explanation of some conceptual and methodological issues, Total Quality Management \& Business Excellence 16(3): 363-380. http://dx.doi.org/10.1080/14783360500053972

Saaty, T. 1980. The analytic hierarchy process: planning, priority setting, resource allocation. New York: McGraw-Hill. 287 p.

Saaty, T. 1990. How to make a decision: the analytic hierarchy process, European Journal of Operational Research 48(1): 9-26. http://dx.doi.org/10.1016/0377-2217(90)90057-I

Saaty, T. 1996. Decision making with dependence and feedback: the analytic network process. Pittsburg, KS, USA: The Organization and Prioritization of Complexity, RWS Publications. 370 p.

Sandt, J.; Schäffer, U.; Weber, J. 2001. Balanced performance measurement systems and manager satisfaction: empirical evidence from a German study. Vallendar: WHU, Lehrstuhl für Betriebswirtschaftslehre, insbesondere Controlling und Telekommunikation. 170 p. 
Shahin, A.; Mahbod, M. 2007. Prioritization of key performance indicators: an integration of analytical hierarchy process and goal setting, International Journal of Productivity and Performance Management 56(3): 226-240.

http://dx.doi.org/10.1108/17410400710731437

Sharif, A. M. 2002. Benchmarking performance management systems, Benchmarking: an International Journal 9(1): $62-85$.

http://dx.doi.org/10.1108/14635770210418588

Simons, R. 2000. Performance measurement \& control systems for implementing strategy. New Jersey: Prentice-Hall.

Sinclair, D.; Zairi, M. 1995a. Effective process management through performance measurement. Part I. Business Process Re-engineering and Management Journal 1(1): 75-88. http://dx.doi.org/10.1108/14637159510798239

Sinclair, D.; Zairi, M. 1995b. Effective process management through performance measurement. Part II benchmarking total quality-based performance measurement for best practice, Business Process Reengineering and Management Journal 1(2): 58-72. http://dx.doi.org/10.1108/14637159510798284

Sinclair, D.; Zairi, M. 1995c. Effective process management through performance measurement. Part III - an integrated model of total quality-based performance measurement, Business Process Re-engineering \& Management Journal 1(3): 50-65.

http://dx.doi.org/10.1108/14637159510103220

Tavana, M.; Banerjee, S. 1995. Strategic assessment model (SAM): a multiple criteria decision support system for evaluation of strategic action, Decision Sciences 26(1): 119-143. http://dx.doi.org/10.1111/j.1540-5915.1995.tb00840.x

Vaidya, O.; Kumar, S. 2006. Analytic hierarchy process: an overview of applications, European Journal of Operational Research 169(1): 1-29.

http://dx.doi.org/10.1016/j.ejor.2004.04.028

van Veen-Dirks, P.; Wijn, M. 2002. Strategic control: meshing critical success factors with the balanced scorecard, Long Range Planning 35(4): 407-427. http://dx.doi.org/10.1016/S0024-6301(02)00066-3

Vukomanović, M.; Radujković, M.; Burcar Dunović, I. 2008. Performance management models in construction companies, Gradevinar 60(9): 771-778.

Yang, C. 2009. Development of an integrated model of a business excellence system, Total Quality Management \& Business Excellence 20(9): 931-944. http://dx.doi.org/10.1080/14783360903181610

Mladen VUKOMANOVIĆ. An Assistant Professor at the University of Zagreb, Croatia. He leads a research project "Business excellence in the construction industry in Croatia". He is the managing editor of Organization, Technology and Management in Construction: An International Journal. He is a member of CIB, IPMA, Performance Measurement Association. His research interests are performance management, key performance indicators, benchmarking, TQM, strategic management in construction, project management processes and IT in construction.

Mladen RADUJKOVIĆ. A full time Professor at the University of Zagreb, Croatia. He is editor-in-chief of the Organization, Technology and Management in Construction: An International Journal, president of the Croatian Association for Project Management and the IPMA vice-president for Research, Education and Training. He leads the research project "Risk and change management in the project oriented construction business". His research interests are project management, risk management, management control systems, scheduling techniques, change management and operational research. 